\title{
ARE 401(K) PLANS REPLACING OTHER EMPLOYER-PROVIDED PENSIONS? EVIDENCE FROM PANEL DATA
}

Leslie E. Papke

Working Paper 5736

\author{
NATIONAL BUREAU OF ECONOMIC RESEARCH \\ 1050 Massachusetts Avenue \\ Cambridge, MA 02138 \\ August 1996
}

I thank John Tumer for helpful comments. This paper is part of NBER's research programs in Aging and Public Economics. Any opinions expressed are those of the author and not those of the National Bureau of Economic Research.

(C) 1996 by Leslie E. Papke. All rights reserved. Short sections of text, not to exceed two paragraphs, may be quoted without explicit permission provided that full credit, including $\mathbb{C}$ notice, is given to the source. 


\title{
ARE 401(K) PLANS REPLACING OTHER \\ EMPLOYER-PROVIDED PENSIONS? \\ EVIDENCE FROM PANEL DATA
}

\begin{abstract}
This paper examines whether sponsors of traditional defined benefit (DB) plans are replacing them with $401(\mathrm{k})$ or other defined contribution (DC) plans. I compare pension plan offerings by sponsors of a DB plan in 1985 with their offerings in 1992 using Form 5500 filings from those two years. I find that $401(\mathrm{k})$ and other DC plans are substituting for terminated DB plans and that offering a DC plan of any type increases the probability of a DB termination. Thus, it appears that, at the sponsor level, many of the new 401(k) plans may not be avenues for net saving but are replacements for the more traditional pension forms.

Using several specifications, I estimate that a sponsor that starts with no $401(\mathrm{k})$ or other DC plan and adds a $401(\mathrm{k})$ is predicted to reduce the number of DB plans offered by at least 0.3 . That is, the estimates imply that one sponsor terminates a DB plan for about every three sponsors that offer one new 401(k) plan. The addition of a non-401(k) DC plan is estimated to reduce DB plan offerings by at least 0.4 .

Plan-level point estimates indicate that if a $401(\mathrm{k})$ plan is added by a sponsor, the DB termination probability increases by about 18 percentage points to 35 percent. The addition of a non401(k) DC plan similarly increases the probability that an accompanying DB plan will be terminated.

Leslie E. Papke

Department of Economics

101 Marshall Hall

Michigan State University

East Lansing, MI 48824

and NBER

PAPKE@MSU.EDU
\end{abstract}




\section{INTRODUCTION}

Traditionally, the primary form of an employer-provided pension has been defined benefit. In a defined benefit plan, retirement payments are described by a formula based on salary and years of service and are funded by employer contributions. The benefit is guaranteed in nominal terms and the employer bears all investment risk. A defined contribution plan, in contrast, establishes an account for each participant with retirement benefits determined solely by the contributions to the account and the investment return. Prior to 1978 , only employers could make pre-tax contributions to defined contribution plans. But, with the advent of the $401(k)$ plan, the ability to make pre-tax contributions was extended to plan participants. ${ }^{1}$

While $401(\mathrm{k}) \mathrm{s}$ plans are provided by an employer, they have become the leading form of tax-deferred retirement saving for individuals. In 1992, $401(k)$ contributions totaled $\$ 64.3$ billion, about 24 percent of personal saving. ${ }^{2}$ During the heyday of the Individual Retirement Account (IRA) from 1982 to 1986, annual IRA contributions averaged only $\$ 34$ billion, and have fallen substantially since the Tax Reform Act of 1986. Recent research has focused on whether individual $401(k)$ contributions represent net saving (Engen, Gale, and Scholz (1994), and Poterba, Venti, and Wise (1995)). Work in this area focuses on the potential substitution between individual contrlbutions and an expanding list of personal financial assets .. conventional liquid assets, IRA contributions, and housing equity, for

\footnotetext{
${ }^{1}$ The $401(k)$ plan was first authorized in 1978, but came into use after the Internal Revenue Service issued clarifying regulations in 1981.

${ }^{2}$ Pension contribution figures are taken from the U.S. Department of Labor, 1996, Tables E14 and E23. NIPA Personal Saving figures are from Table B-26, Economic Report of the President, 1996.
} 
example. Yet, despite concern in the popular press about defined benefit plan phase out in favor of defined contribution plans (see Newsweek, 1993, for example) the 1mportant substitution potential at the employer level has received little attention. Employers may view the $401(\mathrm{k})$ plan as an opportunity to reduce their pension costs since participation in $401(k)$ plans is voluntary.

Contributions to $401(k)$ plans are not only a significant fraction of personal saving, but.now play an increasing role in pension saving. In 1985 , $401(k)$ contributions totaled $\$ 16.3$ billion, about 18 percent of all pension contributions. By $1992,401(k)$ contributions had risen to $\$ 64.3$ billion, and comprised almost 50 percent of all pension contributions (see the Department of Labor, 1996, Tables E14 and E23). This paper explores whether this shift in relative importance is due in part to changing forms of employer penstons. Evidence of plan substitution on the part of the employer would raise a cautionary flag about the degree to which the growth in $401(k)$ plans and assets are net saving.

Despite uncertain effects on net saving, the concept of the individual saving plan as employer-provided pension continues to be popular. Recent legislation creates a variation on the $401(\mathrm{k})$ plan for small business with fewer anti-discrimination requirements called the SIMPLE plan: Savings Incentive Match Plan for Employees. Employees contribute the minimum of up to three percent of salary or $\$ 6,000$ per year. Employers are required to match the contribution, but may temporarily drop their match rate to one percent in unprofitable years. Clearly, it is important to resolve the effects of these tax-deferred saving plans on net saving both on the part of individuals as well as their employers. 
To examine sponsor behavior, I construct a panel of firms that sponsor at least one defined benefit plan in 1985 and compare their pension offerings in 1985 to offerings in 1992 accounting for changes in their 401(k) or other defined contribution plan status. I use a panel of defined benefit plans over the same period to estimate termination probabilities. Of secondary interest is the extent of the (primarily) administrative substitution of $401(k)$ for other defined contribution plans. Many of the early $401(\mathrm{k})$ plans are commonly thought to be converted defined contribution plans (thrift or profit-sharing) that did not have the pre-tax participant-contribution feature.

The next section provides of brief description of $401(\mathrm{k})$ plans and compares them to the more traditional pension forms. Section 3 summarizes existing evidence on the substitution possibilities between defined benefit and $401(k)$ plans. Section 4 describes the data to be used and Section 5 presents econometric evidence at both the sponsor and defined benefit plan level. Section 6 concludes.

\section{BACKGROUND}

Employer-sponsored pre-tax saving plans, often called 401(k) plans, differ from traditional employer-sponsored retirement plans in that eligible employees are permitted to make pre-tax contributions to the plan. Most employers match the contributions (typically with a match rate of 50 percent up to six percent of compensation). The return on the contributions accrues tax-free and taxes are paid at withdrawal. Following the Tax Reform Act of 1986, the employee contribution limit is set at $\$ 7,000$, indexed for inflation. The contribution limit is $\$ 9,235$ for the 1995 tax year. Because the saving is tax-favored, the Internal Revenue Service imposes contribution limits, and 
restricts participant access to the funds. The plan must pass certain nondiscrimination tests to remain tax-qualified. ${ }^{3}$

With the matching provision, a higher contribution limit, and no adjusted gross income phase-out of deductibility, 401(k) plans have a greater potential for pre-tax saving than do Individual Retirement Accounts (IRA). But, unlike an IRA, a 401(k) plan is available only through employers. They are now widely offered by employers. The percentage of employees with an employer who sponsors a $401(\mathrm{k})$ plan increased from 26.9 percent in 1988 to 36.8 percent in 1993 . The fraction of participating workers rose from 57.0 percent to 64.6 percent. ${ }^{4}$

It is not surprising that both employees and employers would prefer plans with a $401(k)$ option to the other types of defined contribution (DC) plans. Employees receive tax-deferred saving and a high instant return if the employer matches even a fraction of their contribution. Employers may find $401(k)$ plans a cost-effective way to offer pension benefits to workers with different preferences. The employer need only make a contribution (if they match) for workers who have already made a contribution. Indeed, Even and Macpherson (1993) find that the probability of an employee participating in a pension plan offered by a firm is lower if the primary plan is a $401(\mathrm{k})$. It is commonly understood that many thrift or saving DC plans without the pre-tax contribution feature were terminated and replaced by a similar 401(k) plan. The extent of this DC conversion is addressed below.

The substitution of a $401(k)$ type of DC plan for a defined benefit (DB)

\footnotetext{
${ }^{3}$ See Papke (1995) for a detailed discussion of contribution limits and nondiscrimination requirements.

"See the Employee Benefit Research Institute, 1994, for eligibility and participation rates calculated from the April 1993 Current Population Survey.
} 
plan is of more interest. Since the plans differ fundamentally in terms of investment risk and portability, switching from a DB to a DC plan with $401(\mathrm{k})$ features implies significant changes in the nature of pension benefits.5 Andrews (1992) documents that most of the $401(k)$ plans that were created in the early 1980s supplemented an already existing DB plan. While it would not be surprising to see DBs terminated by closing firms and 401(k)s created by new firms, a priori, one would expect little replacement of a DB plan by a $401(k)$ in ongoing firms. In fact, this supposition is confirmed by evidence from the early 1980s, as reviewed in the next section.

\section{EXISTING EVIDENCE}

Two strands of 1 iterature address, elther directly or indirectly, substitution between types of pension plans. The first research arose from concern about wide-spread DB terminations during the mid-1970s to mid-1980s, and documents broad economy-wide shifts in the shares of employees covered by types of plans but does not link shifts to changes in plan offerings.

Gustman and Steinmeier (1992) analyze the role of unions, firm size, and industry composition using repeated cross sections from Form 5500 filings. They find that these factors could account for at most half of the decline in primary DB coverage from 1977 to 1985 (from 89.7 percent in 1977 to 79.3 percent in 1985).

Clark and McDermed (1990) estimate that only 3.1 of the 15 percentage point decline in the proportion of DB coverage between 1979 and 1983 can be explained by changes in the size distribution of firms and industrial

\footnotetext{
${ }^{5}$ The behavioral effects of the DB form of pension benefits has been widely studied. See Gustman and Steinmeier (1995) and Turner (1993) for analysis.
} 
composition. Using the 1979 and 1983 Current Population Survey supplements on pension coverage and the 1983 Survey of Consumer Finances, they conclude that demographic, employer size, and broad industry and occupation variables explain none of the coverage decline. They speculate that pension regulation could be responsible for the increased use of DC plans.

Petersen (1992) examines DB terminations without directly addressing the shift to DC plans. He finds that financial factors play a strong role in the decision to terminate overfunded DB plans (greater needs for cash and higher costs in obtaining external capital increase the risk of termination and a reversion of assets).

The issue of plan type substitution is raised with sponsors directly in a recent survey by Papke, Petersen, and Poterba (1996). They find that only one (albelt large) sponsor in their small sample of 43 plans reports a DB termination as a result of $401(k)$ plan introduction between 1986 and 1990 . However, there is evidence of widespread DC conversion, that is, replacement of a thrift/saving or profit-sharing plan with a plan with $401(\mathrm{k})$ features. Forty-five percent of responding firms, representing 37 percent of $401(\mathrm{k})$ participants in the survey, indicate that another pension plan was converted to the $401(\mathrm{k})$. The survey responses indicate that $401(\mathrm{k})$ plans typically supplement a preexisting DB plan (63 percent) or DC plan (19 percent).

The most complete analysis of substitution between DB and DC plans is by Kruse (1995), in which he tabulates participation and assets for the entire pension sector. He matches sponsors using Form 5500 data from 1980 and 1986 to study adoptions and terminations of different types of plans, and estimates the number of employees involved. For each type of plan, he tabulates participant counts for companies that adopt, maintain, or terminate a plan 
(plan categories are DB, All DC, Profit sharing, and Employee Stock Option Plans) over this perlod.

Kruse's key conclusions in the current context are the following:

Very little of the growth in DC participants came from companies that terminated DB plans, with most growth coming from companies with no change in DB status; (2) The largest declines in DB participation came from companies that had no change in DB or DC status; (3) Employee Stock Option Plans (ESOPs, a type of DC plan) tend to supplement rather than replace DB plans. Kruse documents a total of 7.2 million $401(\mathrm{k})$ participants as of 1986 (out of a total of almost 33 million DC participants), but $401(k)$ data are not available for 1980 and he is unable to isolate the effect of the adoption of $401(k) s$ on other plan offerings or participant counts.

These findings are reflected in the aggregate data presented in Table 1. The pension sector over the first half of the 1980 s is broadly characterized by a stable number of net DB plans, and a net increase in the number of and participation in DC plans. While the number of large single employer DC plans (with 100 or more participants) rises from 12,978 to 25,713 over this period, net DB plans are virtually unchanged $(22,424$ in 1980 and 22,426 in 1986).

However, the aggregate data from the latter half of the 1980 s and early 1990 s suggest a need to re-examine the issue of substitution of DC for DB plans. Two changes in particular are noteworthy. First, the net number of DB plans falls dramatically. From 1985 to 1992, the number of large DB plans (over 100 participants) falls 25 percent (from 22,619 to 17,019) while the number of DC plans increases about 64 percent (from 23,279 to 38,283 ). If single employer plans of all sizes are considered, the DB total falls from 167,911 in 1985 to 86,797 in 1992, and the number of single employer DC plans 
increases from 461,158 to 618,429 in 1992 . Changes in the number of active participants mirror these movements. ${ }^{6}$

Second, as Table 1 illustrates, adoption of $401(\mathrm{k})$ plans escalates over this period. The availability of $401(k)$ plans rises from 29,869 in 1985 to 139,704 in 1992. The number of active participants (who may also participate in other plans) more than doubles (from 10.3 million in 1985 to 22.4 million In 1992). Assets rise from $\$ 143.9$ billion to $\$ 552.9$ billion over this period (see the U.S. Department of Labor, 1996, Table E23.)

Papke (1994) uses some preliminary Form 5500 data from the second half of the 1980 s to estimate the effect of $401(k)$ introduction on the characteristics of 3,406 companion defined benefit plans. Using a differenceof differences methodology, she compares changes in defined benefit participation, funding, and the intention to terminate the existing single DB plan, between 1985 and 1991 for plans whose sponsors introduced a 401(k) plan over this period and for plans whose sponsors did not.

Papke finds no evidence that the introduction of a $401(k)$ plan affects defined benefit plans offered by larger sponsors (those with over 200 employees). However, it appears that the smaller sponsors do reduce participation and funding, and are more likely to indicate they intend to terminate their defined benefit plan, once a $401(\mathrm{k})$ plan is introduced.

This paper extends this work in a number of ways. First, the 1985 sample is extended to sponsors of multiple DB plans with at least 100

\footnotetext{
${ }^{6}$ Between 1980 and 1985 , the active participant count in the larger DB plans is relatively stable (21.9 million in 1980 to 21.4 million in 1985), while DC participation increases from 14.8 million to 27.7 million. But from 1985 to 1992, active participation in DB plans falls from 21.6 million to 19.8 million, and participation rises in DC plans from 27 million to 29.5 million. The story is similar if all sizes of single employer plans are considered.
} 
participants so the menu of DB offerings can be examined. Second, the previous analysis is limited to DB plans that are maintained over the period so it misses DB plans that are terminated between 1985 and 1991 . In contrast, this analysis tracks sponsors of DB plans functioning in 1985. The initial DB plan(s) and all related plans are tracked between 1985 and 1992 . I note termination of the original DB plan over the period as well as the reported intention to terminate in the 1992 flling. Third, this paper examines the effect of changes in both the number of $401(k)$ and non-401(k) DC offerings on the sponsor's DB plan. Finally; I estimate the extent of conversion of non$401(k)$ DC plans to $401(k)$ plans. This paper focuses on ongoing sponsors who originally offered a DB plan in 1985, and does not address economy-wide shifts in types of pension coverage.

To summarize, this paper poses two types of questions. The first concerns the menu of plans offered by the sponsor. How do the sponsor's $401(k)$ or other DC plan offerings affect their DB plan(s)? In particular, does the introduction of a new $401(\mathrm{k})$ plan affect DB offerings by that sponsor? What is the extent of DC conversion into $401(k)$ plans? I use a panel of plan sponsors to address these questions. Second, at the plan level, how does a $401(k)$ plan affect the termination probability of the accompanying DB plan? This question is analyzed with a panel of DB plans for those same sponsors. The next section describes the data used to analyze these issues.

\section{SAMPLE CONSTRUCTION}

I use data from the 1985 and 1992 Form 5500 filings available from the Pension and Welfare Benefits Administration of the U.S. Department of Labor to construct two panels. A Form 5500 is filed annually with the Internal Revenue 
Service by all sponsors of pension plans with 100 or more participants. Each plan's report includes information on plan eligibility, participation, employment, administrative cost, distributions, and contributions.

I begin with a sample of all single employer sponsors of DB plans in 1985. Using the Employer Identification Number (EIN) of the sponsor to identify companion plans, I note the number and type of accompanying $401(k)$ and other DC plans for those sponsors and plan characteristics of interest -. participation, eligibility, assets, and coverage.

To construct the panel of sponsors, I match the 1985 list of DB sponsors by EIN to all plan reports by those sponsors in the 1992 Form 5500 filings, the most recent year for which the Form 5500 data are available. I summarize the information on the sponsor's DB plans, and accompanying $401(\mathrm{k})$ and other DC plans. If a DB plan does not appear in the final 1992 filings but its sponsor files a form for other plan(s), the DB plan is considered to be terminated. A DB plan is also considered terminated if the 1992 filing indicates the plan has been terminated (but the sponsor is required to file until all assets are distributed) or indicates that a resolution to terminate the plan has been filed.

To construct the panel of DB plans, I match the DB plans of the sponsors in 1985 to their reports in 1992, again summarizing accompanying DC plan information. While the sponsors must be ongoing in 1992 to enter the sample, the DB plan need not be. That is, as in the panel of sponsors, if a sponsor files for other plans in 1992 but not for the original DB plan, the DB plan is considered to be terminated. ' If the sponsor does not file any Form 5500 in

\footnotetext{
7The absence of a DB plan from the 1992 Form 5500 data when the sponsor has filed for other plans likely indicates a plan termination, but could result from a plan merger that changes the plan number, (about three percent of plans
} 
1992, the DB plan is dropped from the sample since either the sponsor has ceased operation over this period or there has been a filing error.

Since some sponsors offer more than one DC plan - a $401(\mathrm{k})$ and an ESOP, for example -- it is important to clarify how some of the accompanying DC plan characteristics are summarized. The Form 5500 data include measures of plan participation, but it is not possible to determine how many employees participate in more than one plan offered by their employer. It is generally understood that employees participate in only one DB plan, but participation in an accompanying DC plan, or in more than one DC plan is possible. Therefore, when appropriate, I sum characteristics across all accompanying $401(k)$ or other DC plans to create the characteristics of the accompanying plans for the sponsor or for the DB plan.

To summarize the construction of the panels, sponsors of a DB plan in 1985 are matched to their 1992 reports along with accompanying 401(k) and DC plan information. To construct the panel of plans, each DB plan is matched to its 1992 record, if available. A DB plan is considered to be terminated if the sponsor indicates the plan has been terminated or a resolution to terminate the plan has been filed. In addition, if the 1985 DB plan has no match in 1992, but the sponsor reports other plans, the original 1985 DB plan is presumed to have been terminated over the period. Descriptive statistics for the two years of data are presented below.

\section{A. The 1985 Sample}

\footnotetext{
indicate an intention to merge in 1985), or a filing error. Because these two alternatives are not obviously correlated with $401(\mathrm{k})$ introduction, it is not clear what the direction of the bias, if any, would be. I thank Dan Beller for useful discussions on this issue.
} 
The Inltial 1985 sample consists of 16,597 DB plans corresponding to 11,950 distinct sponsors (the plan's sponsors have different EINs - - the terms sponsor and employer will be used interchangeably here). Eighty-three percent of employers offer one DB plan, 10.43 percent offer two DB plans, and 2.86 percent offer three DB plans. The remaining 3.55 percent of employers in the sample offer more than three DB plans.

of the 11,950 employers, 1,586 (13.27 percent) offer one $401(k)$ plan in addition to their DB.plan in 1985. A non-401(k) defined contribution plan (hereafter, a DC plan) is offered by 17.21 percent of these employers; most of these ( 82.63 percent) offered only one DC plan.

Table 2 displays the summary statistics for the 1985 sample of DB plans. While later regression analysis uses only changes in plan status and participation data, other characteristics of interest are summarized as well. Both means and medians are presented since the largest plans dominate the means of some characteristics. Two measures of participation are reported. The first, a response to question $7 \mathrm{a} 4$ on the 1985 Form 5500 ("Total number of active participants at the end of the plan year") indicates an average active participant count of 587 , and a median of 211 . The second measure reported in response to question $17 \mathrm{~h}$ ("Information about employees of employer at end of the plan year: Employees participating") indicates more participants on average, 772 , but a simflar median, 216 .

The average participation rate (participation divided by eligible employees) for DB plans is virtually 100 percent, with an average coverage rate (number of eligible employees divided by total employees) of 57 percent (a median coverage rate of 65 percent). Seventeen percent of DB plans in the sample are accompanied by a $401(\mathrm{k})$ plan. Almost nine percent of DB plans 
reporting in 1985 have been terminated or a resolution to terminate has been filed. The average funding ratio is 1.63 (funding calculations are available from the author). The average age of the DB plans is 18 years, and median plan assets are $\$ 2.33$ million (average assets are $\$ 12.4$ million).

Table 3 reports summary statistics for the $401(k)$ plans that accompany these DB plans in 1985. No sponsor in the sample offered more than one. Both measures of participation indicate that the average $401(\mathrm{k})$ plan has about 1000 participants, although the median plan is much smaller - about 270 . The participation rate is 83.3 percent (using question 794 ), and the average coverage rate 63.7 percent. Most $401(\mathrm{k})$ plans are relatively new in 1985 .the average age is 2.84 years, median assets are $\$ 1.88$ million (average assets are $\$ 11.3$ million), and the calculated average match rate offered is $0.64 .^{8}$

\section{B. The 1992 Sample}

There are two striking changes between the 1985 and 1992 samples that parallel the aggregate data presented in Table 1. First, over 41 percent of the 1985 sponsors exit by 1992, accounting for over 57 percent of the 1985 DB plans. Second, sponsors are three times as likely to sponsor a $401(\mathrm{k})$ in 1992 than in 1985.9

Of the 6,974 ongoing employers from the 1985 sample who appear in the final 1992 Form 5500 filings, 20.78 percent $(1,449)$ offer no DB plan. Thus,

${ }^{8}$ The plan's match rate is not reported on the form. It is calculated as the ratio of employer to employee contributions. See Papke (1995) for a discussion.

${ }^{9}$ I have estimated, but do not report, linear probability models that explain EIN attrition in 1992 based on the 1985 sponsor-level characteristics that are avallable on the Form 5500. The probability of sponsor attrition is associated negatively with the number of plans offered, the DB plan's participation ratio, plan assets, plan age, and positively with a higher ratio of retired or separated participants to actives. The $r$-squares in the models are quite low. 
over twenty percent of the employers still reporting in 1992 drop their 1985 DB plan(s), but retain or add a DC or $401(k)$ plan. The majorfty, 68.30 percent of these employers $(4,763)$, offer one DB plan, 7.26 percent (506) offer two DB plans, 1.82 percent (127) offer three DB plans. The remaining 1.88 percent of employers offer more than three DB plans.

By 1992, more employers offer an accompanying $401(k)$ than a DC plan. While most offer no $401(k)$ plan $(61.40$ percent $(4,282)), 33.68$ percent $(2,349)$ offer one, and 3.87 percent (270) offer two. The remaining 1.08 percent offer more than two $401(k)$ plans. The fraction of employers offering at least one non-401(k) DC plan has also increased. Most of the employers offer no accompanying DC plan (71.36 percent), 23.27 percent offer one, 4.24 percent offer two, and the remaining 1.13 percent offer three or more DC plans.

Table 4 reports the summary statistics for the 1992 sample of DB plans for ongoing sponsors. Two measures of participation are reported. The first, reported in response to question $7 a 4$ (as in 1985, "Total number of active participants as of the end of the plan year") indicates an increase in the average size of DB plans from 587 participants on average in 1985 to 843 . The median has also increased to 257 (from 211).

The second measure of participation is taken from question 21 , which is the most comparable to question $17 \mathrm{~h}$ from 1985 . However, the set of questions concerning employees has been expanded to include questions related to antidiscrimination requirements that are not applicable to DB plans. As a result. many fewer filings contain answers to the subparts of question 21 than to question 17 in 1985 . The participation subpart, question $21 \mathrm{~m}$, ("Enter the number of nonexcludable employees who benefit under the plan") indicates that 
on average 475 employees benefit under the plan(s), 10

Average participation rates in DB plans have fallen relative to 1985

using either measure (to 80 or 88 percent of eligibles). (Note that the

sample size for the rate calculation is halved due to missing values to

question $21 \mathrm{j}$ ("Number of nonexcludable employees"). The DB coverage rate has

increased to 71 percent. About five percent of DB plans still filing in 1992

are terminated or will be terminated. The average funding ratio has fallen to

1.01. (The funding ratio is expected to fall over this period due to the

funding limits in the Omnibus Reconciliation Act of 1987.)

Table 5 reports the summary statistics for the $401(\mathrm{k})$ plans that

accompany a DB plan in 1992 or that are reported by an ongoing firm that

sponsored a DB in 1985. Recall that these characteristics may be sums over multiple $401(\mathrm{k})$ plans if more than one $401(\mathrm{k})$ plan is offered by the employer (about five percent of the sample). Average participation in the $401(\mathrm{k})$

plan(s) has risen since 1985 from 1,067 to 1,592. The participation rate (the sum of all plan participants divided by the sum of eligibles in $401(\mathrm{k}) \mathrm{s}$ ) is about the same, 81.9 percent, and the coverage rate has increased from 63.7 percent in 1985 to 70.3 in 1992. The average match rate has fallen to 0.40 (although the median rate is about the same, 0.33), and the average maximum match rate across plans offered by the same sponsor is 0.42 . Average assets in $401(k)$ plans have increased from $\$ 11.3$ million in 1985 to $\$ 41.7$ in 1992 , and the 1992 median is $\$ 4.71$ million.

\footnotetext{
${ }^{10}$ If Question $21 \mathrm{k}$ ("Do 100 percent of the nonexcludable employees entered on line $21 \mathrm{j}$ benefit under the plan?") is answered affirmatively, then question $21 \mathrm{~m}$ is not completed on the form. The response to question $21 \mathrm{j}$ ("Enter the number of nonexcludable employees") is substituted in the data.
} 


\section{ECONOMETRIC ESTMMATES}

As past work indicates, many factors enter into DB termination. The primary purpose of this paper is to estimate the role of $401(k)$ offerings on a sponsor's DB offerings.

\section{A. Sponsor-level Estimates of Plan Substitution}

Table 6 presents estimates of the effect of the change in the number of $401(k)$ or other DC plan offerings on the change in the number of DB plans offered by the sponsor. Specifying the regression equation in changes over the two years holds constant any characteristics of the sponsor that do not change over the period. The ( $\log$ of) the level of firm employment in 1985 is included rather than the change in firm employment, because firm employment is missing for 45 percent of plans in the 1992 data. ${ }^{11}$

Estimates of the most complete model are presented in column four and indicate that both $401(k)$ and DC plans are substitutes for DB plans. The addition of a $401(k)$ plan over this period results in a reduction of 0.184 of a DB plan. In other words, a DB plan is predicted to be terminated for about every five $401(k)$ plans added. An additional non-401(k) DC plan is estimated to result in a reduction of 0.152 of a DB plan, after controlling for total firm employment in 1985 and industry dummies.

In the sample, 66.12 percent $(4,611$ out of 6,974$)$ of employers do not change the number of $401(k)$ plans offered, and 28.95 percent $(2,019)$ add at least one. The number of net $401(\mathrm{k})$ plans added is 2,071. Thus, the point estimate indicates that these additional $2,071401(k)$ plans are associated with a loss of about 381 DB plans, 10.81 percent of all DB plans lost to

\footnotetext{
${ }^{11}$ Questions about firm employment on the 1992 form move to a nondiscrimination tests section that is not relevant for DB plans.
} 
ongoing sponsors $(3,526$ DB plans).

In the sample, 72.71 percent $(5,033$ out of 6,922$)$ of employers do not change their DC offerings, and 17.77 percent $(1,239)$ add at least one. The net change in DC plans is 700 . The point estimate indicates that these 700 additional DC plans are associated with a loss of about 106 DB plans.

The estimates in Table 6 require that the effect of adding a 401(k) plan is the same (though of opposite sign) as subtracting a $401(k)$ plan. The estimates in Table 7. relax this assumption. Three plan status dummy variables are included for each plan type. The categories are: (1) the firm offers at least one new $401(\mathrm{k})$ plan over this period; (2) the firm maintains the $401(\mathrm{k})$ it had in 1985 and did not add another; (3) the firm loses the $401(\mathrm{k})$ it had in 1985. (No sponsor in the 1985 sample offered more than one 401(k).) Similar dummy categories are defined for non-401(k) DC plans, adjusted for the fact that there may be multiple DC plans in 1985 . The coefficient estimates on these dummy variables are interpreted relative to the base or omftced category: the firm offers no $401(k)$ or DC plan in 1985 or 1992.

The effects of $401(k)$ and DC plan status reported in Table 7 are fairly consistent across the models and again indicate substitution across the plan types. The $r$-squared of the regression indicates that almost 12 percent of the variation in DB plan offerings by sponsors is explained by the status of accompanying $401(k)$ or other DC plans (column 2).

The most complete model is presented in column four and includes the log of firm employment in 1985 and industry dummies. These estimates indicate that the addition of at least one $401(\mathrm{k})$ plan reduces the number of DB plans by 0.312 relative to a sponsor that offers no $401(k)$ or other DC plan. (This is essentially the same as adding one $401(\mathrm{k})$ plan since 85 percent of sponsors 
that add at least one add only one.) This estimate implies that a sponsor terminates a DB plan for about every three sponsors that offer at least one new $401(k)$ plan. Since 2,019 sponsors added at least one $401(k)$, this estimate predicts a loss of 630 DB plans or almost 18 percent of the DB plans lost to ongoing sponsors in the panel.

Maintaining the $401(\mathrm{k})$ offered in 1985 reduces the number of DB plans by 0.213. In the sample, 673 sponsors maintained the $401(\mathrm{k})$ they had in 1985 , so the estimate predicts a termination of 143 DB plans. The t-statistics for these two effects are extremely high. Substitution of a DB for a terminated 401(k) plan is indicated as well, but the coefficient is small and statistically insignificant.

Using 1985 DB average plan characteristics from Table 2, it is possible to estimate the number of participants who lose their DB plan when a $401(\mathrm{k})$ is added. Multiplying the number of predicted DB terminations (630) by one of the two measures of particlpation -- active participants or employees participating - - indicates that between 364,172 and 486,562 participants are involved. These participants represent 4.04 percent of all active participants or 4.91 percent of all employees participating in a DB plan in 1985 .

Non-401(k) DC plans 11ke ESOPS or profit-sharing plans are also estimated to be substitutes for terminated DB plans in two out of three situations. The estimated effects are larger than those for $401(k)$ plans.

The addition of a DC plan reduces the number of DB plans offered by 0.410 . If 2.4 sponsors offer at least one new DC plan, then one DB plan is predicted to be terminated. Since 1,239 DC plans were added, the estimate predicts a loss of 508 DB plans to ongoing sponsors. Maintaining the existing DC leads to a 
termination of 0.264 of a DB plan. But the situation is different if a DC plan is lost. If a sponsor loses a DC plan, it is estimated to also terminate 0.134 of a DB plan. This may reflect Kruse's observation that ESOPS typically supplement DB plans. These supplementary ESOPS appear to be terminated along with the DB plan. These estimated effects are also highly statistically significant. Apparently, despite the different nature of these plans, by the latter half of the 1980s and early 1990s, 401(k)s and other DC plans have begun to replace DB plans.

What is the extent of substitution between new $401(k) s$ and non-401(k) DC plans? Recall that earlier work did find evidence of conversion of DC Into $401(k)$ plans, and this is confirmed in Tables 8 and 9 . The most complete model (column four of Table 9) provides unambiguous evidence of substitution for these plan types as well. The preferred estimates in Table 9 indicate that .241 of a DC plan is terminated for each $401(\mathrm{k})$ added. That is, a sponsor terminates a DC without $401(\mathrm{k})$ features for about every four $401(\mathrm{k}) \mathrm{s}$ added. For every 401 (k) plan maintained over the period, .144 of a DC plan is terminated. And, a terminated $401(k)$ plan leads to .499 of a DC plan.

\section{B. Plan-level Estimates of DB Plan Termination}

How does the change in $401(k)$ or other DC status change the probability that an accompanying DB plan will be terminated? Tables 10 and 11 present linear probability models estimated on the panel of DB plans. The dependent variable equals one if the DB plan is terminated by 1992 and zero otherwise. That is, the dependent variable equals one if the Form 5500 indicates that the plan has been terminated recently, or if a resolution to terminate the plan has been filed, or if the plan is missing from the final 1992 fillngs but the 
sponsor has filed Form 5500s for other plans (presumed terminated).

The estimates in the fourth column of Table 10 indicate that the addition of a $401(\mathrm{k})$ plan over this perlod increases the probability of DB termination by .044 or by 4.4 percentage points. The addition of a DC plan similarly increases the DB termination probability by 4.2 percentage points.

The effects of 1985 firm employment and plan assets continue to be small .. an increase of 10 percent in 1985 firm employment increases the termination probability by 0.37 percentage points, and a 10 percent increase in plan assets reduces the termination probability by .52 percentage points.

In Table 11, the three plan status categories are included for $401(\mathrm{k})$ and DC plans. In column four, which includes industry dummies and controls for firm employment and plan assets in 1985, an additional 401(k) plan is estimated to increase the termination probability of the accompanying DB plan by 15.5 percentage points relative to a DB plan of a sponsor with no $401(k)$ or DC plan. This 15.5 percentage point increase in the probability of termination is large relative to the unconditional termination probability of 35 percent. Maintaining the $401(\mathrm{k})$ plan increases the termination probability by 12.8 percentage points. These two estimates are highly statistically signiflcant. The effect of losing a $401(k)$ is also estimated to increase the termination probability, but the estimated effect is small and measured imprecisely.

Without any controls in the regression (column one), the termination probability for the base case sponsor with no $401(\mathrm{k})$ or other DC plan increases from 0.17 to about 0.35 when a new $401(k)$ is offered. Thus, relative to this base case, the addition of a $401(k)$ doubles the DB termination probability. 
Adding a DC plan increases the DB termination probability by 24.0 percentage points, and maintaining a DC plan increases it by 18.6 percentage points. As in the sponsor-level estimates, the loss of a DC plan is associated with the loss of a DB plan. Losing a DC plan is associated with an increased DB termination probability of 12.4 percentage points. These effects are also highly statistically significant.

To summarize, $401(\mathrm{k})$ plans and DC plans appear to be substitutes for DB plans over this period. Adding a $401(k)$ plan essentially doubles the DB termination probability. Losing a $401(k)$ plan has no effect on the DB plan. Adding (or maintaining) a non-401(k) DC plan also increases DB termination probabilities. But, if a sponsor terminates a DC plan, it is also more likely to terminate the accompanying DB plan. Losses of non-401(k) DC and DB plans move together.

C. Changes in DB and Non-401(k) DC Plan Participation

Given the legal complications of plan termination, substitution between a defined benefit and $401(k)$ plan may be a more subtle process. If employers are gradually replacing defined benefit coverage with $401(k)$ coverage, defined benefit participation may decline over time as employers offer only the $401(k)$ plan to new employees. ${ }^{12}$ Table 12 presents estimates of the effect of changes in $401(k)$ and DC plan status on particlpation in the accompanying DB plan.

The estimates in the second column of Table 12 indicate that adding a

${ }^{12}$ Since participation in an avallable DB plan is usually mandatory, the participation ratio (active participants divided by employees eligible) may not reflect this shift. It is more likely that the coverage ratio (eligibles divided by total employees) will reflect this subtle shift. Unfortunately, the coverage ratio can not be calculated for 45 percent of plans in the 1992 sample. 
401(k) reduces DB plan participation by 105.5 employees. This is 18.25

percent of the average participation in a 1985 DB plan (578 participants), and is half of the participants in the median plan (211 participants). This estimate is statistically significant at the five percent level. The estimated effect of maintaining a $401(k)$ plan is small (a loss of 35 DB participants) and is statistically insignificant. Losing a $401(\mathrm{k})$ is estimated to also reduce DB participation (by 111.7 participants) but is also imprecisely measured:

Changes in DC status have a larger effect on DB participation and all three categorles are statistically significant at the five percent level. Offering a new DC plan reduces DB participation by 146.0 employees and maintaining a DC over the period reduces DB participation by 288.9 employees. As in the regressions where a loss of a DC plan is associated with a loss of a DB plan, losing DC participants also is associated with losing DB participants $(166.9)$.

When other covarlates are added, however, only the coefficients on adding and maintaining a DC plan maintain their economic and statistical significance. Offering a new DC reduces DB participation by 100.4 employees, and maintaining the DC reduces DB participation by 250.4 employees. Overall, the r-squareds in these regressions are quite small, indicating that not much variation in DB participation is being explained by changes in $401(k)$ or DC plan status.

The effect of $401(k)$ status on non- $401(k)$ DC participation is analyzed in Table 13. While the preferred estimates in column four indicate that the participation in $401(k)$ and DC plans indicates substitution, again not much variation is explained by plan offerings. 


\section{CONCLUSION}

This paper examines the changes in pension offerings and plan participation for sponsors that began with at least one DB plan in 1985. Between 1985 and 1992 , over 20 percent of ongoing sponsors dropped DB plans entirely in favor of DC-type plans. The econometric evidence indicates that DB offerings are reduced when a sponsor introduces either a $401(k)$ or other DC plan. That 1s, for many ongoing sponsors, $401(k)$ and other DC-type plans are replacing their traditional DB plan. In addition, many of the "new" $401(\mathrm{k})$ plans appear to be converted from DC plans without the pre-tax participant contribution feature.

The addition of a $401(\mathrm{k})$ plan is estimated to reduce the number of DB plans by about 0.3 relative to a sponsor that offers no $401(k)$ or other DC plan. That is, one sponsor terminates a DB plan for about every three sponsors that offer at least one new $401(k)$ plan. In the sample, this effect accounts for almost 18 percent of the DB plans lost to ongoing sponsors in the panel and the DB loss affects four to five percent of all 1985 DB participants. Maintaining the $401(\mathrm{k})$ offered in 1985 reduces the number of DB plans by about 0.2 .

Non-401(k) DC plans are also estimated to reduce DB plan offerings, and the estimated effects are larger than those for $401(k)$ plans. The addition of a DC plan reduces the number of DB plans offered by about 0.4 . Maintaining the existing DC leads to a termination of 0.26 of a DB plan.

Addition of a $401(\mathrm{k})$ plan also substantially increases the probability that an accompanying DB plan will be terminated. The point.estimates indicate that if a $401(\mathrm{k})$ plan is added by a sponsor, the DB termination probability increases by about 18 percentage points to 35 percent. The addition of a non- 
401(k) plan similarly increases the probability that a DB plan w111 be terminated.

This evidence indicates that $401(\mathrm{k})$ plans are substituting for the traditional DB and DC thrift/saving type plans among sponsors that have offered DB plans in the past. While the estimates are suggestive, there are several important caveats to bear in mind. First, a change in the number or type of plan offered does not necessarily change pension coverage. It is possible that sponsors are consolidating plans, and as mentioned above, a limitation of this data is that it is not possible to track participants to specific plans. Further, a change in pension form, from DB to $401(k)$, has no necessary effect on the amount of eventual retirement assets. Large individual contributions, a possible company match, and good investment performance may lead to a larger income at retirement than the company's DB formula.

Third, for the twenty percent of employers who replaced all DB plans with $401(k)$ or DC plans, it is clear that a fundamental change in the nature of pension benefits has taken place. But the qualitative nature of that change is not considered here. It may be that participants prefer the DC pension form that offers portability and frequently, participant-direction of assets.

The evidence presented does suggest, however, that not all the assets in new $401(k)$ plans represent net saving. $401(k)$ assets may in part replace saving that formerly took place in a DB plan or in an DC plan without $401(\mathrm{k})$ features .

The debate over whether $401(\mathrm{k})$ plans and other types of individual saving plans generate enough new saving to justify their large tax expenditure 
is still ongoing. In assessing their effects on saving, prior research has focused on whether participant contributions substitute for other forms of personal financial assets. But, since $401(\mathrm{k})$ plans are an employer-provided form of retirement saving, the extent of substitution for other forms of pensions must also be explored in assessing the efflcacy of $401(\mathrm{k})$ plans. 


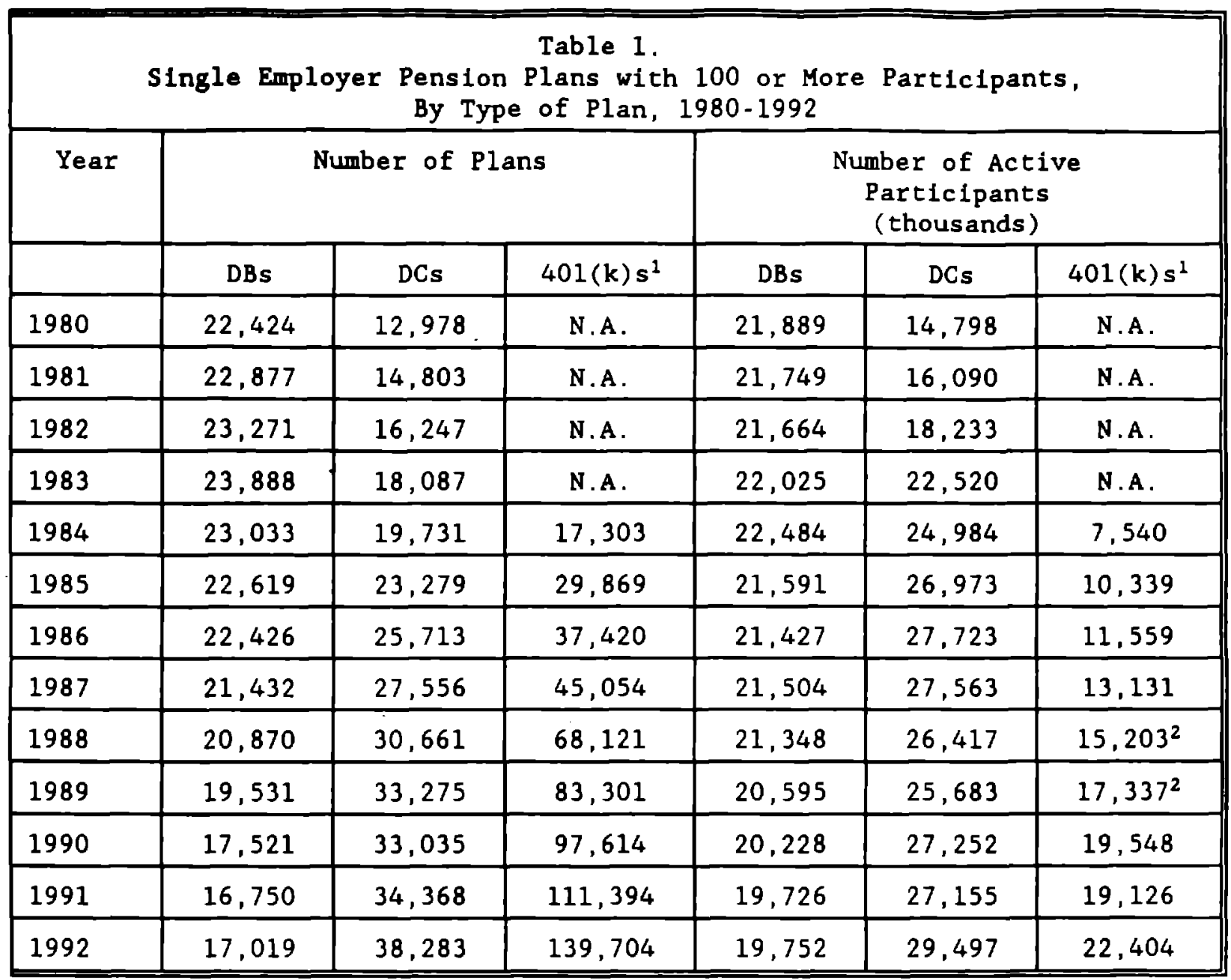

1 401(k) plans include all plan sizes and entity types.

${ }^{2}$ Includes some employees who are eligible to participate but have not elected to join.

Source: U.S. Department of Labor, Pension and Welfare Benefits Adminlstration, "Private Pension Plan Bulletin: Abstract of 1992 Form 5500 Annual Reports," Number 5, Winter 1996, Tables E3, E10, and E23. 


\begin{tabular}{|c|c|c|c|}
\hline Summary Statistics for & $\begin{array}{c}\text { Table } 2 . \\
\text { Sample of Primary } \\
1985\end{array}$ & Defined Bene & t Plans \\
\hline & $\begin{array}{c}\text { Mean } \& \text { Standard } \\
\text { Deviation }\end{array}$ & Median & Obs. \\
\hline $\begin{array}{l}\text { Active participants } \\
\text { (Q7a4) }\end{array}$ & $\begin{array}{c}578.05 \\
(4283.95)\end{array}$ & 211 & 15,589 \\
\hline $\begin{array}{l}\text { Employees participating } \\
\text { (Q17h) }\end{array}$ & $\begin{array}{r}772.32 \\
(5.119 .05) \\
\end{array}$ & 216 & 12,841 \\
\hline $\begin{array}{l}\text { Employees eligible } \\
\text { (Q17f) }\end{array}$ & $\begin{array}{c}804.17 \\
(5,265.13)\end{array}$ & 220 & 12,529 \\
\hline $\begin{array}{l}\text { Total employment } \\
\text { (Q17b) }\end{array}$ & $\begin{array}{c}11,536.71 \\
(475,230.90) \\
\end{array}$ & 686 & 15,476 \\
\hline $\begin{array}{l}\text { Actives participation } \\
\text { ratio } \\
\text { (Q7a4/Q17f) }\end{array}$ & $\begin{array}{c}0.955 \\
(0.152)\end{array}$ & 1.000 & 10,920 \\
\hline $\begin{array}{l}\text { Employee } \\
\text { Participation ratio } \\
\text { (Q17h/Q17f) }\end{array}$ & $\begin{array}{l}0.989 \\
(0.069)\end{array}$ & 1.000 & 12,468 \\
\hline $\begin{array}{l}\text { Coverage ratio } \\
(\mathrm{Q} 17 \mathrm{f} / \mathrm{Q} 1 \mathrm{~b})\end{array}$ & $\begin{array}{c}0.570 \\
(0.317)\end{array}$ & 0.650 & 12,436 \\
\hline Existing $401(\mathrm{k}) ?$ & $\begin{array}{c}0.170 \\
(0.376)\end{array}$ & - & 16,597 \\
\hline $\begin{array}{l}\text { Terminated or intend to } \\
\text { terminate? }\end{array}$ & $\begin{array}{l}0.088 \\
(0.283)\end{array}$ & - & 16,597 \\
\hline Consolidated or merged? & $\begin{array}{c}0.034 \\
(0.180)\end{array}$ & $\cdots$ & 16,597 \\
\hline Funding ratio & $\begin{array}{l}1.63 \\
(0.62)\end{array}$ & 1.62 & 9,137 \\
\hline Plan age & $\begin{array}{c}18.07 \\
(11.24)\end{array}$ & 17 & 16,456 \\
\hline $\begin{array}{l}\text { Plan assets } \\
\text { (\$millions) }\end{array}$ & $\begin{array}{c}12.4 \\
(179.0)\end{array}$ & 2.33 & 15,662 \\
\hline
\end{tabular}

Note: Q7a4 refers to question 7, part a4 on the 1985 Form 5500 and other data items are similarly identified. Standard errors are in parentheses. 
Table 3 .

Summary Statistics for Accompanying 401(k) Plans 1985

\begin{tabular}{|c|c|c|c|}
\hline & $\begin{array}{c}\text { Mean \& } \\
\text { Standard } \\
\text { Deviation }\end{array}$ & Median & Obs. \\
\hline $\begin{array}{l}\text { Active participants } \\
(\mathrm{Q} 7 \mathrm{a} 4)\end{array}$ & $\begin{array}{c}1067.46 \\
(4813.37)\end{array}$ & 281.5 & 1,574 \\
\hline $\begin{array}{l}\text { Employees participating } \\
\text { (Q17h) }\end{array}$ & $\begin{array}{l}1,017.23 \\
(4,930.88)\end{array}$ & 271 & 1,424 \\
\hline $\begin{array}{l}\text { Employees eligible } \\
\text { (Q17f) }\end{array}$ & $\begin{array}{c}1,572.21 \\
(14,223.27)\end{array}$ & 326 & 1,387 \\
\hline $\begin{array}{l}\text { Total employment } \\
(\mathrm{Q} 17 \mathrm{~b})\end{array}$ & $\begin{array}{r}4,392.72 \\
(21,858.39) \\
\end{array}$ & 650 & 1,543 \\
\hline $\begin{array}{l}\text { Actives participation } \\
\text { rat1o } \\
\text { (Q7a4/Q17E) }\end{array}$ & $\begin{array}{l}0.833 \\
(0.184)\end{array}$ & 0.882 & 1,280 \\
\hline $\begin{array}{l}\text { Employee } \\
\text { Participation ratio } \\
\text { (Q17h/Q17f) }\end{array}$ & $\begin{array}{l}0.844 \\
(0.181)\end{array}$ & 0.897 & 1,381 \\
\hline $\begin{array}{l}\text { Coverage ratio } \\
\text { (Q17f/Q17b) }\end{array}$ & $\begin{array}{c}0.637 \\
(0.272) \\
\end{array}$ & 0.692 & 1,383 \\
\hline Plan age & $\begin{array}{r}2.84 \\
(2.91) \\
\end{array}$ & 1.0 & 1,586 \\
\hline Match rate & $\begin{array}{r}0.64 \\
(0.78) \\
\end{array}$ & 0.39 & 980 \\
\hline $\begin{array}{l}\text { Plan assets } \\
\text { ( } \$ \text { millions) }\end{array}$ & $\begin{array}{c}11.3 \\
(48.9)\end{array}$ & 1.88 & 1,508 \\
\hline
\end{tabular}

Note: Q7a4 refers to question 7, part a4 on the 1985 Form 5500 and other data items are similarly identified. Standard errors are in parentheses. 


\begin{tabular}{|c|c|c|c|}
\hline Summary Statistics for & $\begin{array}{c}\text { Table } 4 . \\
\text { Sample of Primary } \\
1992\end{array}$ & Defined Bene & t Plans \\
\hline & $\begin{array}{c}\text { Mean \& Standard } \\
\text { Deviation }\end{array}$ & Median & Obs. \\
\hline $\begin{array}{l}\text { Active participants } \\
(\text { Q7a4) }\end{array}$ & $\begin{array}{c}842.80 \\
(4,635.84)\end{array}$ & 257 & 7,004 \\
\hline $\begin{array}{l}\text { Employees benefiting } \\
(Q 21 \mathrm{~m})\end{array}$ & $\begin{array}{r}475.38 \\
(3,600.00) \\
\end{array}$ & 0.0 & 5,573 \\
\hline $\begin{array}{l}\text { Employees eligible } \\
(Q 21 j)\end{array}$ & $\begin{array}{r}1,287.04 \\
(5,457.09\end{array}$ & 168 & 6,225 \\
\hline $\begin{array}{l}\text { Total employment } \\
\text { (Q21h) }\end{array}$ & $\begin{array}{c}2,270.62 \\
(10,740.18) \\
\end{array}$ & 241 & 6,260 \\
\hline $\begin{array}{l}\text { Actives participation } \\
\text { ratio } \\
(\mathrm{Q} 7 \mathrm{a} 4 / \mathrm{Q} 21 \mathrm{j})\end{array}$ & $\begin{array}{c}0.805 \\
(0.308)\end{array}$ & 0.976 & 3,244 \\
\hline $\begin{array}{l}\text { Employee } \\
\text { Participation ratio } \\
\text { (Q21m/Q21j) }\end{array}$ & $\begin{array}{l}0.875 \\
(0.258)\end{array}$ & 1.000 & 3,898 \\
\hline $\begin{array}{l}\text { Coverage ratio } \\
(\mathrm{Q} 21 \mathrm{~J} / \mathrm{Q} 21 \mathrm{~h})\end{array}$ & $\begin{array}{c}0.707 \\
(0.232) \\
\end{array}$ & 0.766 & 3,861 \\
\hline Existing $401(k) ?$ & $\begin{array}{l}0.389 \\
(0.488)\end{array}$ & -- & 7,017 \\
\hline $\begin{array}{l}\text { Terminated or intend to } \\
\text { terminate? }\end{array}$ & $\begin{array}{c}0.052 \\
(0.221) \\
\end{array}$ & -- & 7,017 \\
\hline Consolidated or merged? & $\begin{array}{c}0.038 \\
(0.191) \\
\end{array}$ & -- & 7,017 \\
\hline Funding ratio & $\begin{array}{c}1.01 \\
(0.38)\end{array}$ & 0.96 & 5,938 \\
\hline Plan age & $\begin{array}{c}24.09 \\
(11.21) \\
\end{array}$ & 23 & 2,976 \\
\hline $\begin{array}{l}\text { Plan assets } \\
\text { (\$m1lilons) }\end{array}$ & $\begin{array}{c}32.6 \\
(414.0)\end{array}$ & 5.25 & 7,017 \\
\hline
\end{tabular}

Note: Q7a4 refers to question 7, part a4 on the 1985 Form 5500 and other data items are similarly identified. Standard errors are in parentheses. 


\begin{tabular}{|c|c|c|c|}
\hline \multicolumn{4}{|c|}{$\begin{array}{c}\text { Table } 5 . \\
\text { Summary Statistics for Accompanying } 401(\mathrm{k}) \text { Plans } \\
1992\end{array}$} \\
\hline & $\begin{array}{l}\text { Mean \& } \\
\text { Standard } \\
\text { Deviation }\end{array}$ & Median & Obs. \\
\hline $\begin{array}{l}\text { Active participants } \\
(Q 7 a 4)\end{array}$ & $\begin{array}{r}1,592.30 \\
(8,862.04) \\
\end{array}$ & 353 & 2,633 \\
\hline $\begin{array}{l}\text { Employees benefiting } \\
\text { (Q21m) }\end{array}$ & $\begin{array}{r}1,502.17 \\
(5,025.1) \\
\end{array}$ & 356.5 & 2,362 \\
\hline $\begin{array}{l}\text { Employees eligible } \\
(Q 21 j)\end{array}$ & $\begin{array}{c}2,584.03 \\
(11,133.69) \\
\end{array}$ & 395 & 2,379 \\
\hline $\begin{array}{l}\text { Total employment } \\
\text { (Q21h) }\end{array}$ & $\begin{array}{c}5,306.11 \\
(33,365.35)\end{array}$ & 643 & 2,384 \\
\hline $\begin{array}{l}\text { Actives participation } \\
\text { ratio } \\
(Q 7 a 4 / Q 21 j)\end{array}$ & $\begin{array}{c}0.819 \\
(0.244)\end{array}$ & 0.923 & 1,994 \\
\hline $\begin{array}{l}\text { Employee } \\
\text { participation ratio } \\
\text { (Q21m/Q21j) }\end{array}$ & $\begin{array}{c}0.906 \\
(0.211)\end{array}$ & 1.000 & 2,358 \\
\hline $\begin{array}{l}\text { Coverage ratio } \\
\text { (Q21m/Q21h) }\end{array}$ & $\begin{array}{c}0.703 \\
(0.236) \\
\end{array}$ & 0.767 & 2,378 \\
\hline Average firm match rate & $\begin{array}{c}0.40 \\
(0.37) \\
\end{array}$ & 0.33 & 2,054 \\
\hline Maximum match rate & $\begin{array}{c}0.42 \\
(0.38) \\
\end{array}$ & 0.34 & 2,145 \\
\hline $\begin{array}{l}\text { Plan assets } \\
\text { (\$millions) }\end{array}$ & $\begin{array}{c}41.7 \\
(251.0) \\
\end{array}$ & 4.71 & 2,637 \\
\hline
\end{tabular}

Note: Q7a4 refers to question 7, part a4 of the 1992 Form 5500 and other data items are similarly identifled. Standard errors are in parentheses. 


\begin{tabular}{|c|c|c|c|}
\hline \multicolumn{4}{|c|}{$\begin{array}{c}\text { Table } 6 . \text { OLS Regression } \\
\text { Dependent Variable: Change in the Number of DB Pla } \\
\text { Offered by the Firm Between } 1985 \text { and } 1992\end{array}$} \\
\hline $\begin{array}{l}\text { Change in the number of } \\
401(\mathrm{k}) \text { plans between } 1985 \\
\text { and } 1992\end{array}$ & $\begin{array}{l}.210 \\
(.012) \\
{[.019]}\end{array}$ & $\begin{array}{l}-.205 \\
(.012) \\
{[.019]}\end{array}$ & $\begin{array}{l}-.184 \\
(.012) \\
{[.019]}\end{array}$ \\
\hline $\begin{array}{l}\text { Change in the number of DC } \\
\text { plans between } 1985 \text { and } \\
1992\end{array}$ & $\begin{array}{l}. .139 \\
(.013) \\
{[.018]}\end{array}$ & $\begin{array}{l}-.146 \\
(.013) \\
{[.018]}\end{array}$ & $\begin{array}{l}-.152 \\
(.013) \\
{[.018]}\end{array}$ \\
\hline $\begin{array}{l}\text { Log (firm employment } \\
\text { in 1985) }\end{array}$ & & $\begin{array}{l}-.062 \\
(.005) \\
{[.008]}\end{array}$ & $\begin{array}{l}-.062 \\
(.005) \\
{[.008]}\end{array}$ \\
\hline Industry dummies? & no & no & yes \\
\hline Constant & $\begin{array}{l}-.285 \\
(.009) \\
{[.009]}\end{array}$ & $\begin{array}{l}.128 \\
(.036) \\
{[.046]}\end{array}$ & $\begin{array}{c}.217 \\
(.041) \\
{[.048]}\end{array}$ \\
\hline Obs. & 6,854 & 6,554 & 6,554 \\
\hline $\mathrm{R}^{2}$ & .0462 & .0681 & .0931 \\
\hline
\end{tabular}

The usual oLs standard errors are in parentheses; heteroskedasticity-robust standard errors are in brackets. 


\begin{tabular}{|c|c|c|c|}
\hline $\begin{array}{c}\text { Table } \\
\text { Dependent Variable: } \\
\text { Offered by the }\end{array}$ & $\begin{array}{l}\text { 7. OLS Regre } \\
\text { Change in the } \\
\text { Firm Between }\end{array}$ & $\begin{array}{l}\text { Lon } \\
\text { umber of DB } \\
85 \text { and } 1992\end{array}$ & Plans \\
\hline $\begin{array}{l}\text { Firm offers at least one } \\
\text { new } 401(\mathrm{k}) \text { plan }\end{array}$ & $\begin{array}{l}-.346 \\
(.018) \\
{[.020]}\end{array}$ & $\begin{array}{l}-.336 \\
(.018) \\
{[.020]}\end{array}$ & $\begin{array}{l}-.312 \\
(.018) \\
{[.021]}\end{array}$ \\
\hline $\begin{array}{l}\text { Firm maintains its } 401(k) \\
\text { plan }\end{array}$ & $\begin{array}{l}-.250 \\
(.026) \\
{[.027]}\end{array}$ & $\begin{array}{l}-.219 \\
(.026) \\
{[.027]}\end{array}$ & $\begin{array}{l}-.213 \\
(.027) \\
{[.028]} \\
\end{array}$ \\
\hline $\begin{array}{l}\text { Firm loses one } 401(k) \\
\text { plan }\end{array}$ & $\begin{array}{l}-.040 \\
(.037) \\
{[.048]}\end{array}$ & $\begin{array}{l}-.010 \\
(.037) \\
{[.047]}\end{array}$ & $\begin{array}{l}.005 \\
(.037) \\
{[.047]} \\
\end{array}$ \\
\hline $\begin{array}{l}\text { Firm offers at least one } \\
\text { new DC plan }\end{array}$ & $\begin{array}{l}-.423 \\
(.021) \\
{[.024]}\end{array}$ & $\begin{array}{l}-.403 \\
(.021) \\
{[.023]}\end{array}$ & $\begin{array}{l}-.410 \\
(.021) \\
{[.024]}\end{array}$ \\
\hline $\begin{array}{l}\text { Firm maintains its } \\
\text { DC plan(s) }\end{array}$ & $\begin{array}{l}-.312 \\
(.027) \\
{[.029]}\end{array}$ & $\begin{array}{l}-.269 \\
(.027) \\
{[.028]}\end{array}$ & $\begin{array}{l}-.264 \\
(.027) \\
{[.029]}\end{array}$ \\
\hline $\begin{array}{l}\text { Firm loses at least one } \\
\text { DC plan }\end{array}$ & $\begin{array}{l}-.193 \\
(.027) \\
{[.037]}\end{array}$ & $\begin{array}{l}-.148 \\
(.028) \\
{[.038]}\end{array}$ & $\begin{array}{l}-.134 \\
(.027) \\
{[.037]}\end{array}$ \\
\hline $\begin{array}{l}\text { Log(firm employment in } \\
1985 \text { ) }\end{array}$ & & $\begin{array}{l}-.050 \\
(.005) \\
{[.008]}\end{array}$ & $\begin{array}{l}-.050 \\
(.005) \\
{[.008]} \\
\end{array}$ \\
\hline Industry dummies? & no & no & yes \\
\hline Constant & $\begin{array}{l}-.113 \\
(.011) \\
{[.008]} \\
\end{array}$ & $\begin{array}{l}.206 \\
(.035) \\
{[.046]}\end{array}$ & $\begin{array}{l}.233 \\
(.040) \\
{[.047]} \\
\end{array}$ \\
\hline Obs. & 6,854 & 6,554 & 6,554 \\
\hline $\mathrm{R}^{2}$ & .1179 & .1274 & .1441 \\
\hline
\end{tabular}

Note: The omitted category is the firm offers no $401(\mathrm{k})$ plan or other DC plan. The usual ols standard errors are in parentheses; heteroskedasticity. robust standard errors are in brackets. 


\begin{tabular}{|c|c|c|c|}
\hline $\begin{array}{r}\text { Table } \\
\text { Dependent Varlable: } \\
\text { Offered by the }\end{array}$ & $\begin{array}{l}\text { 8. OLs Regre } \\
\text { Change in the } \\
\text { Firm Between }\end{array}$ & $\begin{array}{l}\text { ssion } \\
\text { Number of DC } \\
1985 \text { and } 1992\end{array}$ & Plans \\
\hline $\begin{array}{l}\text { Change in the number of } \\
401(\mathrm{k}) \text { plans between } 1985 \\
\text { and } 1992\end{array}$ & $\begin{array}{l}-.206 \\
(.011) \\
{[.017]}\end{array}$ & $\begin{array}{l}-.200 \\
(.011) \\
{[.017]}\end{array}$ & $\begin{array}{l}-.192 \\
(.011) \\
{[.018]}\end{array}$ \\
\hline $\begin{array}{l}\text { Log (firm employment } \\
\text { in 1985) }\end{array}$ & & $\begin{array}{l}-.009 \\
(.005) \\
{[.006]}\end{array}$ & $\begin{array}{l}-.005 \\
(.005) \\
{[.006]}\end{array}$ \\
\hline Industry dummies? & no & no & yes \\
\hline Constant & $\begin{array}{l}.160 \\
(.008) \\
{[.008]}\end{array}$ & $\begin{array}{l}.216 \\
(.034) \\
{[.038]}\end{array}$ & $\begin{array}{l}.186 \\
(.039) \\
{[.041]}\end{array}$ \\
\hline Obs. & 6,922 & 6,618 & 6,618 \\
\hline $\mathrm{R}^{2}$ & .0473 & .0473 & .0621 \\
\hline
\end{tabular}

The usual OLS standard errors are in parentheses; heteroskedasticity-robust standard errors are in brackets. 


\begin{tabular}{|c|c|c|c|}
\hline $\begin{array}{r}\text { Table } \\
\text { Dependent Variable: } \\
\text { Offered by the }\end{array}$ & $\begin{array}{l}\text { 9. OLS Regr } \\
\text { Change in th } \\
\text { Firm Between }\end{array}$ & $\begin{array}{l}\text { ion } \\
\text { Number of DC } \\
985 \text { and } 1992\end{array}$ & Plans \\
\hline $\begin{array}{l}\text { Firm offers at least one } \\
\text { new } 401(\mathrm{k}) \text { plan }\end{array}$ & $\begin{array}{l}-.260 \\
(.016) \\
{[.017]}\end{array}$ & $\begin{array}{l}-.248 \\
(.017) \\
{[.018]}\end{array}$ & $\begin{array}{l}-.241 \\
(.017) \\
{[.019]} \\
\end{array}$ \\
\hline $\begin{array}{l}\text { Firm maintains its } 401(k) \\
\text { plan }\end{array}$ & $\begin{array}{l}-.141 \\
(.025) \\
{[.026]}\end{array}$ & $\begin{array}{l}-.133 \\
(.026) \\
{[.027]}\end{array}$ & $\begin{array}{l}-.144 \\
(.026) \\
{[.027]} \\
\end{array}$ \\
\hline $\begin{array}{l}\text { Firm loses one } 401(k) \\
\text { plan }\end{array}$ & $\begin{array}{l}.494 \\
(.034) \\
{[.042]}\end{array}$ & $\begin{array}{l}.505 \\
(.035) \\
{[.043]}\end{array}$ & $\begin{array}{l}.499 \\
(.035) \\
{[.042]} \\
\end{array}$ \\
\hline $\begin{array}{l}\text { Log(firm employment in } \\
1985)\end{array}$ & & $\begin{array}{l}-.015 \\
(.005) \\
{[.006]}\end{array}$ & $\begin{array}{l}-.011 \\
(.005) \\
{[.006]} \\
\end{array}$ \\
\hline Industry dummies? & no & no & yes \\
\hline Constant & $\begin{array}{l}.165 \\
(.010) \\
{[.008]}\end{array}$ & $\begin{array}{l}.259 \\
(.034) \\
{[.038]}\end{array}$ & $\begin{array}{l}.226 \\
(.039) \\
{[.040]} \\
\end{array}$ \\
\hline Obs. & 6,922 & 6,618 & 6,618 \\
\hline $\mathrm{R}^{2}$ & .0754 & .0747 & .0903 \\
\hline
\end{tabular}

Note: The omitted category is the firm offers no $401(k)$. The usual oLS standard errors are in parentheses; heteroskedasticity-robust standard errors are in brackets. 


\begin{tabular}{|c|c|c|c|}
\hline $\begin{aligned} \text { Table 10. } & \text { L } \\
\text { Dependent Varlable: } & \text { I }\end{aligned}$ & $\begin{array}{l}\text { Linear Probabi } \\
\text { Is the DB Plan }\end{array}$ & $\begin{array}{l}\text { Lity Model } \\
\text { Terminated b }\end{array}$ & $1992 ?$ \\
\hline $\begin{array}{l}\text { Change in the number of } \\
401(k) \text { plans between } 1985 \\
\text { and } 1992\end{array}$ & $\begin{array}{l}.064 \\
(.005) \\
{[.011]}\end{array}$ & $\begin{array}{l}.049 \\
(.005) \\
{[.010]}\end{array}$ & $\begin{array}{l}.044 \\
(.005) \\
{[.009]}\end{array}$ \\
\hline $\begin{array}{l}\text { Change in the number of DC } \\
\text { plans between } 1985 \text { and } \\
1992\end{array}$ & $\begin{array}{l}.046 \\
(.007) \\
{[.013]}\end{array}$ & $\begin{array}{l}.041 \\
(.007) \\
{[.012]}\end{array}$ & $\begin{array}{l}.042 \\
(.007) \\
{[.012]} \\
\end{array}$ \\
\hline $\begin{array}{l}\text { Log (firm employment in } \\
1985 \text { ) }\end{array}$ & & $\begin{array}{l}.038 \\
(.003) \\
{[.005]} \\
\end{array}$ & $\begin{array}{l}.037 \\
(.003) \\
{[.004]} \\
\end{array}$ \\
\hline $\begin{array}{l}\log (p \operatorname{an} \text { assets } \\
\text { in } 1985)\end{array}$ & & $\begin{array}{l}-.054 \\
(.003) \\
{[.003]}\end{array}$ & $\begin{array}{l}-.052 \\
(.003) \\
{[.003]} \\
\end{array}$ \\
\hline Industry dummies? & no & no & yes \\
\hline Constant & $\begin{array}{l}.313 \\
(.005) \\
{[.007]}\end{array}$ & $\begin{array}{l}.829 \\
(.045) \\
{[.049]} \\
\end{array}$ & $\begin{array}{l}.747 \\
(.048) \\
{[.053]} \\
\end{array}$ \\
\hline Obs. & 9,693 & 8,819 & 8,819 \\
\hline $\mathrm{R}^{2}$ & .0183 & .0586 & .0739 \\
\hline
\end{tabular}

The mean of the dependent variable is 0.346 with a standard error of 0.476 . The usual OLS standard errors are in parentheses; standard errors that are robust to heteroskedasticity and within-EIN correlation are in brackets. 
Table 11. Linear Probability Model

Dependent Variable: Is the DB Plan Terminated by 1992?

\begin{tabular}{|c|c|c|c|}
\hline $\begin{array}{l}\text { Firm offers at least one } \\
\text { new } 401(k) \text { plan }\end{array}$ & $\begin{array}{l}.183 \\
(.011) \\
{[.016]}\end{array}$ & $\begin{array}{c}.166 \\
(.011) \\
{[.015]}\end{array}$ & $\begin{array}{c}.155 \\
(.011) \\
{[.016]}\end{array}$ \\
\hline $\begin{array}{l}\text { Firm maintains its } 401(\mathrm{k}) \\
\text { plan }\end{array}$ & $\begin{array}{c}.152 \\
(.016) \\
{[.022]} \\
\end{array}$ & $\begin{array}{c}.141 \\
(.016) \\
{[.022]} \\
\end{array}$ & $\begin{array}{l}.128 \\
(.016) \\
{[.022]}\end{array}$ \\
\hline $\begin{array}{l}\text { Firm loses one } 401(k) \\
\text { plan }\end{array}$ & $\begin{array}{l}.032 \\
(.021) \\
{[.031]}\end{array}$ & $\begin{array}{c}.037 \\
(.021) \\
{[.031]}\end{array}$ & $\begin{array}{c}.027 \\
(.021) \\
{[.031]}\end{array}$ \\
\hline $\begin{array}{l}\text { Firm offers at least one } \\
\text { new DC plan }\end{array}$ & $\begin{array}{l}.265 \\
(.012) \\
{[.019]}\end{array}$ & $\begin{array}{l}.246 \\
(.013) \\
{[.020]}\end{array}$ & $\begin{array}{l}.240 \\
(.013) \\
{[.020]}\end{array}$ \\
\hline $\begin{array}{l}\text { Firm maintains its DC } \\
\text { plan(s) }\end{array}$ & $\begin{array}{l}.224 \\
(.016) \\
{[.023]} \\
\end{array}$ & $\begin{array}{l}.191 \\
(.016) \\
{[.023]} \\
\end{array}$ & $\begin{array}{l}.186 \\
(.016) \\
{[.023]} \\
\end{array}$ \\
\hline $\begin{array}{l}\text { Firm loses at least one } \\
\text { DC plan }\end{array}$ & $\begin{array}{l}.138 \\
(.015) \\
{[.023]}\end{array}$ & $\begin{array}{c}.128 \\
(.015) \\
{[.023]}\end{array}$ & $\begin{array}{l}.124 \\
(.015) \\
{[.023]}\end{array}$ \\
\hline $\begin{array}{l}\log (f 1 \text { rm employment in } \\
1985)\end{array}$ & & $\begin{array}{c}.025 \\
(.003) \\
{[.005]}\end{array}$ & $\begin{array}{c}.026 \\
(.003) \\
{[.005]}\end{array}$ \\
\hline $\log (p \operatorname{lan}$ assets in 1985) & & $\begin{array}{l}. .057 \\
(.003) \\
{[.003]}\end{array}$ & $\begin{array}{l}-.056 \\
(.003) \\
{[.003]}\end{array}$ \\
\hline Industry dummies? & no & no & yes \\
\hline Constant & $\begin{array}{l}.170 \\
(.007) \\
{[.050]}\end{array}$ & $\begin{array}{l}.834 \\
(.043) \\
{[.008]}\end{array}$ & $\begin{array}{l}.803 \\
(.047) \\
{[.054]}\end{array}$ \\
\hline obs. & 9,693 & 8,819 & 8,819 \\
\hline $\mathbf{R}^{2}$ & .0918 & .1217 & .1276 \\
\hline
\end{tabular}

Note: The omitted category is the firm offers no $401(\mathrm{k})$ or other DC plan. The mean of the dependent variable is 0.346 with a standard error of 0.476 . The usual OLS standard errors are in parentheses; standard errors that are robust to heteroskedasticity and within-EIN correlation are in brackets. 


\begin{tabular}{|c|c|c|c|}
\hline $\begin{array}{rr} & \text { Tabl } \\
\text { Dependent Variable: } & \text { Chang } \\
\end{array}$ & $\begin{array}{l}\text { 12. OLS Reg } \\
\text { In DB PartiC }\end{array}$ & $\begin{array}{l}\text { ssion } \\
\text { ation Between }\end{array}$ & 1985 and 1992 \\
\hline $\begin{array}{l}\text { Firm offers at least one } \\
\text { new } 401(k) \text { plan }\end{array}$ & $\begin{array}{r}-105.537 \\
(50.561) \\
{[66.798]}\end{array}$ & $\begin{array}{l}-81.950 \\
(54.015) \\
{[57.289]}\end{array}$ & $\begin{array}{l}-44.545 \\
(56.142) \\
{[55.379]}\end{array}$ \\
\hline $\begin{array}{l}\text { Firm maintains its } 401(k) \\
\text { plan }\end{array}$ & $\begin{array}{l}-35.103 \\
(75.237) \\
{[47.954]}\end{array}$ & $\begin{array}{l}24.884 \\
(80.400) \\
{[66.622]}\end{array}$ & $\begin{array}{c}62.588 \\
(81.742) \\
{[69.740]}\end{array}$ \\
\hline $\begin{array}{l}\text { Firm loses one } 401(k) \\
\text { plan }\end{array}$ & $\begin{array}{c}-111.719 \\
(99.120) \\
{[111.355]}\end{array}$ & $\begin{array}{c}-38.926 \\
(105.908) \\
{[117.273]}\end{array}$ & $\begin{array}{c}4.491 \\
(106.699) \\
{[118.681]}\end{array}$ \\
\hline $\begin{array}{l}\text { Firm offers at least one } \\
\text { new DC plan }\end{array}$ & $\begin{array}{r}-146.012 \\
(59.380) \\
{[33.080]} \\
\end{array}$ & $\begin{array}{r}-108.826 \\
(63.863) \\
{[44.440]} \\
\end{array}$ & $\begin{array}{r}-100.392 \\
(64.133) \\
{[44.911]} \\
\end{array}$ \\
\hline $\begin{array}{l}\text { Firm maintains its } D C \\
\text { plan(s) }\end{array}$ & $\begin{array}{r}-288.920 \\
(76.505) \\
{[190.931]} \\
\end{array}$ & $\begin{array}{r}-253.886 \\
(81.461) \\
{[176.663]} \\
\end{array}$ & $\begin{array}{r}-250.409 \\
(81.837) \\
{[178.976]} \\
\end{array}$ \\
\hline $\begin{array}{l}\text { Firm loses at least one } \\
\text { DC plan }\end{array}$ & $\begin{array}{r}-166.851 \\
(70.275) \\
{[73.469]} \\
\end{array}$ & $\begin{array}{l}-84.600 \\
(75.564) \\
{[93.397]} \\
\end{array}$ & $\begin{array}{l}-53.420 \\
(75.943) \\
{[96.634]} \\
\end{array}$ \\
\hline $\begin{array}{l}\log (\text { firm employment in } \\
1985)\end{array}$ & & $\begin{array}{l}-51.652 \\
(14.807) \\
{[33.924]} \\
\end{array}$ & $\begin{array}{l}-41.768 \\
(15.233) \\
{[31.729]} \\
\end{array}$ \\
\hline Log (plan assets in 1985) & & $\begin{array}{l}-84.445 \\
(14.874) \\
{[59.794]} \\
\end{array}$ & $\begin{array}{l}-98.133 \\
(15.415) \\
{[63.874]} \\
\end{array}$ \\
\hline Industry dummies? & no & no & yes \\
\hline Constant & $\begin{array}{r}61.101 \\
(34.732) \\
{[20.779]} \\
\end{array}$ & $\begin{array}{c}1631.053 \\
(219.160) \\
{[1101.386]} \\
\end{array}$ & $\begin{array}{l}1768.62 \\
(237.406) \\
{[1150.400]}\end{array}$ \\
\hline Obs. & 9,262 & 8,658 & 8,658 \\
\hline $\mathrm{R}^{2}$ & .0031 & .0095 & .0128 \\
\hline
\end{tabular}

Note: The omitted category is the firm offers no $401(k)$ or other DC plan. The mean of the dependent variable is -60.731 with a standard deviation of $2,165.519$. The usual OLS standard errors are in parentheses; heteroskedasticity-robust standard errors are in brackets. 


\begin{tabular}{|c|c|c|c|}
\hline \multicolumn{4}{|c|}{$\begin{array}{c}\text { Table 13. OLS Regression } \\
\text { Dependent Variable: Change in DC Participation Between } 1985 \text { and } \\
1992\end{array}$} \\
\hline $\begin{array}{l}\text { Firm offers at least one } \\
\text { new } 401(k) \text { plan }\end{array}$ & $\begin{array}{r}-298.877 \\
(79.506) \\
{[89.469]}\end{array}$ & $\begin{array}{r}-281.078 \\
(81.658) \\
{[85.797]}\end{array}$ & $\begin{array}{r}-289.030 \\
(85.638) \\
{[88.795]}\end{array}$ \\
\hline $\begin{array}{l}\text { Firm maintains its } 401(\mathrm{k}) \\
\text { plan }\end{array}$ & $\begin{array}{l}-154.010 \\
(120.672) \\
{[168.693]}\end{array}$ & $\begin{array}{l}-170.126 \\
(125.682) \\
{[173.767]}\end{array}$ & $\begin{array}{l}-186.884 \\
(128.253) \\
{[170.162]} \\
\end{array}$ \\
\hline $\begin{array}{l}\text { Firm loses one } 401(k) \\
\text { plan }\end{array}$ & $\begin{array}{l}601.471 \\
(174.152) \\
{[171.960]}\end{array}$ & $\begin{array}{c}578.198 \\
(177.587) \\
{[176.697]}\end{array}$ & $\begin{array}{c}562.034 \\
(179.714) \\
{[178.241]}\end{array}$ \\
\hline $\begin{array}{l}\log (\text { firm employment in } \\
1985 \text { ) }\end{array}$ & & $\begin{array}{l}34.242 \\
(25.060) \\
{[72.491]}\end{array}$ & $\begin{array}{l}34.725 \\
(25.293) \\
{[72.078]}\end{array}$ \\
\hline Industry dummies? & no & no & yes \\
\hline Constant & $\begin{array}{l}100.375 \\
(46.764) \\
{[29.404]}\end{array}$ & $\begin{array}{l}-117.054 \\
(165.351) \\
{[443.917]}\end{array}$ & $\begin{array}{l}-163.041 \\
(188.326) \\
{[437.354]}\end{array}$ \\
\hline obs. & 5,944 & 5,725 & 5,725 \\
\hline $\mathrm{R}^{2}$ & .0053 & .0051 & .0053 \\
\hline
\end{tabular}

Note: The omitted category is the firm offers no $401(\mathrm{k})$. The mean of the dependent variable is -245.279 with a standard deviation of 5,189.370. The usual OLS standard errors are in parentheses; heteroskedasticity-robust standard errors are in brackets. 


\section{REFERENCES}

Andrews, E.S. "The Growth and Distribution of $401(\mathrm{k})$ Plans," in Trends in Pensions 1992, J.A. Turner and D.J. Beller, eds., U.S. Department of Labor, Pension and Welfare Benefits Administration, 1992, 149-176.

Clark, R.L., and A.A. McDermed, The Choice of Pension Plans in a Changing Regulatory Environment, Washington D.C., AEI Press, 1990.

Employee Benefit Research Institute, "Salary Reduction Plans and Individual Saving for Retirement," November 1994.

Engen, E., W.G. Gale, and J.K. Scholz, "Do Savings Incentives Work?" Brookings Papers on Economic Activity, Spring 1994, 85-150.

Even, W.E., and D.A. Macpherson, "Why Did Male Pension Coverage Decline in the 1980s?," mimeo, Miami University, March 1993.

Gustman, A.L., and T.L. Steinmeier, "The Stampede Toward Defined Contribution Pension Plans: Fact or Fiction?" Industrial Relations, Volume 31, No. 2, Spring 1992, 361-369.

Gustman, A.L., and T.L. Steinmeier, Pension Incentives and Job Mobility, W.E. Upjohn Institute for Employment Research, Kalamazoo, Michigan, 1995.

Kruse, D.L., "Pension Substitution in the 1980s: Why the Shift Toward Defined Contribution Plans?" Industrial Relations, Volume 34, No. 2, April 1995. $218-241$.

Newsweek, "Retirement Blues: How Safe is Your Pension?" December 6, 1993, pp. $38-40$.

Papke, L.E., "Does 401(k) Introduction Affect Defined Benefit Plans?" National Tax Association Proceedings of the Eighty-Sixth Annual Conference, 1994 , $122-123$.

Papke, L.E., "Participation in and Contributions to 401(k) Pension Plans: Evidence from Plan Data," Journal of Human Resources, Volume 30, No. 2, Spring 1995, 311-325.

Papke, L.E., M.A. Petersen, and J.M. Poterba, "Do 401(k) Plans Replace Other Employer Provided Pensions?" in Adyances in the Economics of Aging, D. Wise, ed. NBER, University of Chicago Press, 1996, 219-239.

Petersen, M.A., "Pension Reversions and Worker-Stockholder Wealth Transfers," Quarterly Journal of Economics, August 1992, $1033-1056$.

Poterba, J.M., S.F. Venti, and D.A. Wise, "Do $401(\mathrm{k})$ Contributions Crowd Out Other Personal Saving?" Journal of Public Economics, Volume 58, 1995, 132. 
Turner, J.A., Penston Policy for a Mobile Labor Force, W.E. Upjohn Institute for Employment Research, Kalamazoo, Michigan, 1993.

U.S. Department of Labor, Pension and Welfare Benefits Administration, Office of Research and Economic Development, "Private Pension Plan Bulletin: Abstract of 1992 Form 5500 Annual Reports," Number 5, Winter 1996. 